\title{
Dormancy of Bowdichia virgilioides Kunth seeds
}

\author{
Dormência de sementes de Bowdichia virgilioides Kunth
}

\begin{abstract}
Josemara Ferreira dos SANTOS ${ }^{1}$; Andrea Vita Reis MENDONÇA ${ }^{2}$; Manuela Oliveira de SOUZA ${ }^{3}$
${ }^{1}$ Mestranda pelo Programa de Pós-graduação em Recursos Genéticos Vegetais da Universidade Federal do Recôncavo da Bahia (UFRB). Rua Rui Barbosa, , Cruz das Almas - BA, CEP. 44380-000. mara-santtos@hotmail.com

${ }^{2}$ Professora Associada, Centro de Ciências Agrárias Ambientas e Biológicas (CCAAB) Universidade Federal do Recôncavo da Bahia, andrea@ufrb.edu.br

${ }^{3}$ Autor para correspondência, Professora Adjunta. Centro de Ciências Exatas e Tecnológicas CETEC. Universidade Federal do Recôncavo da Bahia, manuelasouza@ufrb.edu.br
\end{abstract}

Recebido em: 01-06-2020; Aceito em: 29-06-2020

\begin{abstract}
The degree of maturity of fruits and seeds can influence the establishment of seed dormancy. Thus, the present study aimed to verify whether dormancy of $B$. virgilioides seeds depends on the degree of fruit maturity. Two experiments were carried out: in the first one, fruits at two maturity stages (green and brown) were collected from seven plants located in the municipality of Conceição da Feira, BA, Brazil. Germination tests were conducted in a completely randomized design in a $2 \times 2$ factorial scheme, with two levels of fruit maturity (yellowish green with purple edges and brown with blackish spots) and two treatments related to dormancy overcoming (without overcoming and with overcoming). For the second experiment, darkened fruits were collected from three plants located in the municipality of Cruz das Almas, BA, Brazil. Germination tests were conducted according to a completely randomized design with two treatments, seeds with and without dormancy overcoming. Dormancy in $B$. virgilioides seeds depends on the degree of fruit maturity. Dormancy occurs after the seventh week of floral anthesis when the fruits are predominantly black, dry and brittle.
\end{abstract}

Additional keywords: fruit maturity stage; germination; 'sucupira preta'

\begin{abstract}
Resumo
O grau de maturação de frutos e de sementes pode influenciar no estabelecimento da dormência de sementes. Assim, objetivou-se com este trabalho verificar se a dormência de sementes de $B$. virgilioides depende do grau de maturação do fruto. Realizaram-se dois experimentos, no primeiro foram coletados frutos em sete matrizes situadas no município de Conceição de Feira, em dois estádios de maturação (verdes e marrons). Os testes de germinação foram conduzidos em delineamento inteiramente casualizado em esquema fatorial $2 \times 2$, com dois estádios de maturação (verdes amarelados com bordas arroxeadas e marrons com regiões enegrecidas) e dois tratamentos relativos à superação de dormência (sem superação e com superação). Para o segundo experimento, coletou-se frutos marrons com regiões enegrecidas em três matrizes situadas no município de Cruz das Almas. Foram realizados testes de germinação, conforme delineamento inteiramente casualizado com dois tratamentos, sementes com e sem superação de dormência. A dormência em sementes de $B$. virgilioides depende do grau de maturação do fruto. $O$ estabelecimento da dormência ocorre após a sétima semana de antese floral quando os frutos estão predominantemente enegrecidos, secos e quebradiços.
\end{abstract}

Palavras-chave adicionais: estádio de maturação do fruto; germinação; sucupira preta.

\section{Introduction}

Bowdichia virgilioides Kunth is a native tree that is distributed throughout the Brazilian territory (Silva et al., 2015; Cardoso, 2019). It has pharmacological potential (Botini et al., 2015; Machado et al., 2018; Silva et al., 2019) and has application in organic production, since its leaves induce the ripening of bananas, replacing calcium carbonate $\left(\mathrm{CaCO}_{3}\right)$, a harmful compound to human health (Nascimento et al., 2019). The wood of this species has commercial value and is used for the fabrication of furniture and in civil construction (Lorenzi, 2009).
Studies conducted since the 1990s have shown that $B$. virgilioides seeds have dormancy due to impermeability of the protective cover (seed coat) (Andrade et al., 1997; Smiderle et al., 2003; Albuquerque et al., 2007; Smiderle \& Schwengber, 2011; RosaMagri \& Meneghin, 2014; Coêlho et al., 2019). The Instructions for Analysis of Seeds of Forest Species (Brasil, 2013) record that seeds of this species have seed coat dormancy and indicate pre-germination treatment with chemical scarification using sulfuric acid for 5 to 10 minutes. Another study proves the efficiency of immersing seeds in water at temperature of $100 \stackrel{\circ}{ } \mathrm{C}$ to overcome dormancy (Smiderle \& Schwengber, 2011). 
Dormancy in seeds is strongly influenced by genetic factors, but it also responds to environmental factors that act in their stage of formation, which explains the existence of varying degrees of dormancy in the same species between different places of origin (Bewley et al., 2013). The impediment of germination may vary depending on the position of the seeds in the pod (Nogueira et al., 2010), on the mother tree (Müller et al., 2016) and on the sites of collection (Botezelli et al., 2000).

In addition to genetic and environmental factors, studies confirm that the degree of fruit and seed maturity also influences the establishment of dormancy (Nakagawa et al., 2007; Nogueira et al., 2013; Müller et al., 2016; Leite et al., 2019). The impediment of germination due to seed coat impermeability can be avoided if the seeds are collected at the point of physiological maturity (Cardoso, 2009). Thus, the hypothesis was raised that for $B$. virgilioides dormancy sets in after the point of physiological maturity.

Therefore, given the ecological and economic importance of $B$. virgilioides, added to the fact that it is a species whose dormancy has been confirmed in several studies, the objective was to verify whether the dormancy of its seeds depends on the degree of fruit maturity.

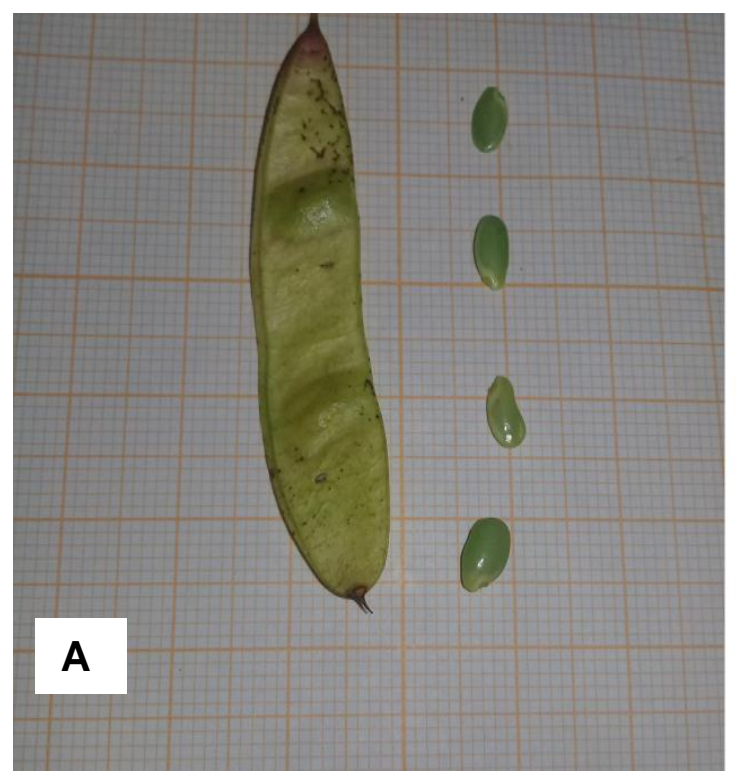

\section{Material and methods}

Two experiments were carried out at the Laboratory of Ecology and Forest Restoration of the Universidade Federal do Recôncavo da Bahia (UFRB), on the campus of Cruz das Almas, Bahia, Brazil.

\section{Experiment 1}

In the first experiment, the fruits were manually collected from seven parent plants located in the municipality of Conceição de Feira - Bahia, Brazil, at $12^{\circ} 27^{\prime} 05.8$ South latitude and $38^{\circ} 59^{\prime} 20.1$ West longitude, in December 2018. After harvest, the fruits were sent to the laboratory, processed and classified by color, according to Almeida (2013). Seeds were obtained from fruits at two maturity stages: A - yellowish green fruits with purplish edges, corresponding to the maturity of five weeks after floral anthesis (Almeida, 2013) and B brown fruits with darkened regions, corresponding to the seventh week after floral anthesis (Almeida, 2013) (Figure 1).

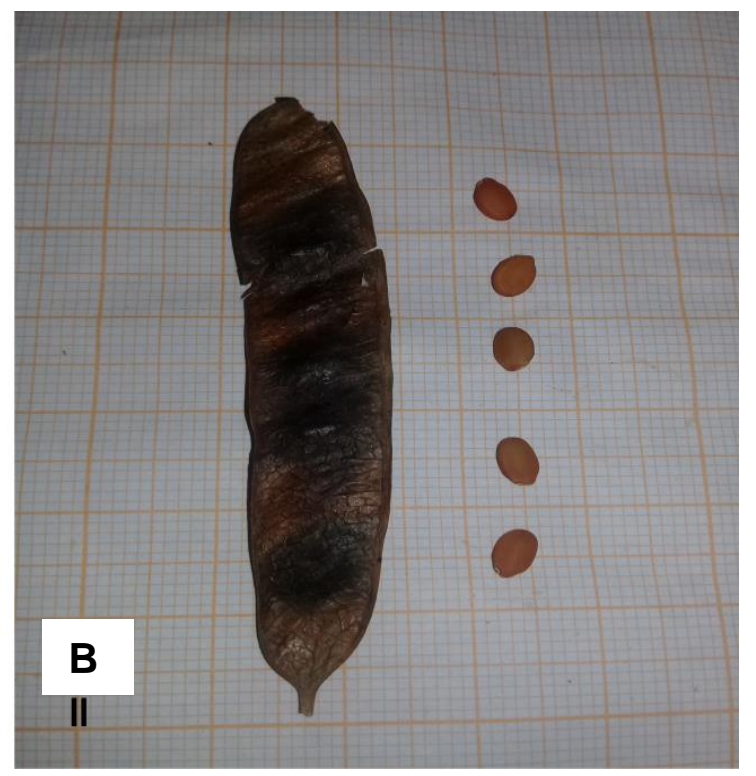

Figure 1 - Fruits and seeds of Bowdichia virgilioides Kunth collected from seven parent plants located in the municipality of Conceição da Feira - Bahia, Brazil. A - yellowish green fruits with purplish edges and B - brown fruits with darkened regions.

The moisture content of the recently harvested seeds was determined by the method of drying in an oven at $105 \pm 3^{\circ} \mathrm{C}$ for 24 hours (Brasil, 2009), using four sub-samples of 1 gram of seeds.

The experimental design was completely randomized in a $2 \times 2$ factorial scheme, with two levels of fruit maturity (yellowish green fruits with purplish edges and brown fruits with darkened regions) and two treatments related to dormancy overcoming (without dor- mancy overcoming and with dormancy overcoming), with four replicates of 25 seeds each. Therefore, a total of four treatments were used: T1 (seeds from yellowish green fruits with purplish edges with dormancy overcoming), T2 (seeds from yellowish green fruits with purplish edges without dormancy overcoming), T3 (seeds from brown fruits with darkened regions with dormancy overcoming) and T4 (seeds from brown fruits with darkened regions without dormancy overcoming). 
For the treatment of dormancy overcoming, the seeds were immersed in distilled water at $100{ }^{\circ} \mathrm{C}$ for 10 seconds (Smiderle \& Schwengber, 2011).

For the germination tests, four replicates of 25 seeds were arranged in germitest paper rolls, moistened with distilled water in a volume equivalent to 2.5 times the weight of the dry paper (g). Then, the rolls were placed in transparent plastic bags, which were kept in a B.O.D. (Biochemical Oxygen Demand) germination chamber with constant temperature of $30^{\circ} \mathrm{C}$ and photoperiod of $12 \mathrm{~h}$ (Brasil, 2013). Daily counts were performed until germination stabilized.

The variables evaluated in this experiment were germination percentage, percentage of normal seedlings, percentage of unviable seeds, mean germination time (Bewley et al., 2013), and shoot length and primary root length of normal seedlings, considering the initial number of seeds (Guedes et al., 2009).

Generalized linear models were applied for analysis of the variables (random component): proportion of germinated seeds, proportion of normal seedlings, proportion of unviable seeds and proportion of hard seeds, in a total of 25 seeds, according to Carvalho et al. (2018). The systematic component corresponds to the treatments employed. Inferences of the analysis (deviance) for binomial distribution, with logit link function, were based on the Chi-Square statistic. To verify the amplitudes of differences between treatments, tests of multiple comparisons of means with Tukey fit were used, with correction of confidence interval by the Šidák method, through the packages emmeans (Lenth et al., 2020) and multcompView (Graves et al., 2019), used in the R Core Team 3.5.3 program. (R development core team, 2019).

For the variables mean germination time and mean length of shoot and primary root of normal seedlings, analysis of variance and means comparison tests (Tukey, $\alpha=0.05$ ) were used. All statistical analyses were performed with the software $\mathrm{R}$ version 3.5.3 (R Core Team, 2019).

\section{Experiment 2}

For the second experiment, fruits of $B$. virgilioides located at $12^{\circ} 39^{\prime} 43$ South latitude and $39^{\circ} 05^{\prime} 51$ West longitude were collected. Three flowering trees were marked in October 2019 and visited weekly to observe the fruits. The fruits were collected on February 19, 2020, after the seventh week of floral anthesis (Almeida, 2013), predominantly darkened, very dry and brittle. The moisture content of the recently harvested seeds was determined by the oven method at $105 \pm 3 \stackrel{\circ}{\mathrm{C}}$ for 24 hours (Brasil,2009), using four 1-ram sub-samples.

The experiment was conducted in a completely randomized design with two treatments, seeds subjected to the procedure to overcome dormancy (immersed in distilled water at $100{ }^{\circ} \mathrm{C}$ for 10 seconds) and not subjected to any pre-germination treatment, with 10 replicates and 25 seeds per replicate.
Four replicates of 25 seeds were arranged in germitest paper rolls, moistened with distilled water in a volume equivalent to 2.5 times the weight of the dry paper $(\mathrm{g})$. Then, the rolls were placed in transparent plastic bags, which were kept in a B.O.D. germination chamber with constant temperature of $30{ }^{\circ} \mathrm{C}$ and photoperiod of $12 \mathrm{~h}$. Daily counts were performed until 34 days. The end of the counts was defined based on the stabilization of germination, which occurred after one week without germination event.

The variables evaluated in this experiment were germination percentage, percentage of normal seedlings, percentage of unviable seeds and percentage of hard seeds.

For the treatment that showed germination, the confidence interval for binomial probability was obtained for the variables under study through the exact method (Pearson-Klopper), using the binom package (DoraiRaj, 2014).

\section{Results and discussion}

\section{Experiment 1}

The average initial moisture content of seeds from green fruits was $54.13 \%$, Confidence IntervalCl95\%: $54.13 \% \pm 1.04 \%$. Seeds from brown fruits showed moisture content of $14.67 \%$, Confidence Interval-Cl $195 \%$ : $14.67 \% \pm 0.18 \%$. Both the degree of fruit maturity, differentiated by green and brown colors, and the dormancy overcoming procedures influenced germination, formation of normal seedlings and unviable seeds (Table 1).

Seeds harvested from green fruits whose dormancy was overcome with hot water did not germinate and rotted, leading to $100 \%$ of unviable seeds (Table 2). Seeds obtained from green fruits without the application of pre-germination treatment showed germination percentage of $99.2 \%$ (Table 2). These results allow for two important inferences. The first is that, depending on the degree of maturity of the seeds, certain pre-germination treatments, such as immersion in water at a temperature of $100^{\circ} \mathrm{C}$, can cause damage to the embryo, instead of promoting germination. The other inference is that seeds harvested from yellowish green fruits with purplish edges, which corresponds to the point of maturity, as indicated by Almeida (2013), did not show dormancy.

For seeds collected from brown fruits, the treatment without dormancy overcoming resulted in a higher germination percentage (93.6\%), while exposure of seeds to water at $100^{\circ} \mathrm{C}$ caused reduction in germination (63.2\%) (Table 2). The percentages of normal seedlings and unviable seeds also revealed lower performance of the treatment with exposure of seeds to hot water for seeds obtained from green and brown fruits (Table 2). Thus, seeds collected from brown fruits with darkened spots were not dormant. These results indicate that the green and brown fruits were harvested before the seeds acquired dormancy. 
Table 1 - Analysis of deviance for the germination of Bowdichia virgilioides Kunth, in response to temperatures, modeled by binomial distribution, with logistic link function.

\begin{tabular}{|c|c|c|c|}
\hline \multirow{2}{*}{ Source of variation } & \multicolumn{3}{|c|}{ Germination } \\
\hline & Deviance & Deviance difference & p-value (Chi-Square) \\
\hline Null & & 432.99 & \\
\hline Color (C) & 45.961 & 387.03 & $<0.0001$ \\
\hline Overcoming (O) & 311.393 & 75.64 & $<0.0001$ \\
\hline CXO & 60.486 & 15.15 & $<0.0001$ \\
\hline AIC & \multicolumn{3}{|c|}{51.075} \\
\hline \multicolumn{4}{|c|}{ Normal seedlings } \\
\hline Source of variation & Deviance & Deviance difference & p-value (Chi-Square) \\
\hline Null & - & 422.76 & \\
\hline Color (C) & 39.001 & 383.76 & $<0.0001$ \\
\hline Overcoming $(\mathrm{O})$ & 308.231 & 75.53 & $<0.0001$ \\
\hline CXO & 59.584 & 15.95 & $<0.0001$ \\
\hline $\mathrm{AIC}$ & \multicolumn{3}{|c|}{54.563} \\
\hline Source of variation & Deviance & $\begin{array}{l}\text { Unviable seeds } \\
\text { Deviance difference }\end{array}$ & p-value (Chi-Square) \\
\hline Null & - & 507.17 & \\
\hline Color (C) & 138.49 & 368.68 & $<0.0001$ \\
\hline Overcoming (O) & 334.64 & 34.05 & $<0.0001$ \\
\hline $\mathrm{CXO}$ & 13.09 & 20.96 & 0.0003 \\
\hline AIC & \multicolumn{3}{|c|}{42.325} \\
\hline
\end{tabular}

AIC - Akaike information criterion

Table 2 - Percentages of germination, normal seedlings and unviable seeds of Bowdichia virgilioides Kunth

\begin{tabular}{lcrrrrr}
\hline \multirow{2}{*}{ Treatments } & \multicolumn{2}{c}{$\%$ Germination } & \multicolumn{2}{c}{$\%$ Normal seedlings } & \multicolumn{2}{c}{$\%$ Unviable seeds } \\
\cline { 2 - 7 } & \multicolumn{1}{c}{ Brown } & \multicolumn{1}{c}{ Green } & \multicolumn{1}{c}{ Brown } & \multicolumn{1}{c}{ Green } & \multicolumn{1}{c}{ Brown } & \multicolumn{1}{c}{ Green } \\
\hline Water $100 \stackrel{\circ}{ } \mathrm{C}$ & $63.2 \pm 9.6 \mathrm{~b}$ A & $0.0 \pm 0.0 \mathrm{~b}$ B & $59.2 \pm 9.8$ b A & $0.0 \pm 0.0$ b B & $10.4 \pm 6.2$ a B & $100.0 \pm 0.0$ a A \\
No overcoming & $93.6 \pm 4.9$ a B & $99.2 \pm 1.8$ a A & $92.8 \pm 5.2$ a B & $98.4 \pm 2.6$ a A & $0.8 \pm 1.8$. b A & $0.8 \pm 1.8$. b A \\
\hline
\end{tabular}

Means followed by confidence intervals, fitted by the Šidák method, and followed by distinct letters, lowercase in columns and uppercase in rows, differ by Tukey test, at 0.05 significance level.

Results reported in studies conducted by Nogueira et al. (2013), Müller et al. (2016) and Leite et al. (2019) demonstrated that other species of the Fabaceae family also do not have dormancy at the point of maturity.

Nogueira et al. (2013) classified the fruits of Mimosa caesalpiniifolia Benth. into five degrees of maturity based on color and defined stage 5 (dry on the ground) as the maturity point, although this stage did not differ statistically from 3 and 4 for germination percentage. In the stage 3 there was no significant difference between treatment with $(85 \%)$ and without $(87 \%)$ dormancy overcoming. These authors also concluded that a high percentage of germination was obtained in seeds harvested from pods with light brown color (stage 3) without dormancy overcoming treatments.

Müller et al. (2016) separated the fruits of Peltophorum dubium (Spreng) Taub. into five stages of maturity based on color. In stages I and II there was no germination, in stage III germination was equal to $48 \%$, in IV to $75 \%$ and in V stage to $18 \%$. Thus, at the stage of maximum vigor and germination (IV), the seeds were not dormant. These authors attributed the reduction of germination in stage $V$ to the possible acquisition of dormancy, but they did not apply dormancy overcoming treatments or tetrazolium tests to confirm this assumption.

Leite et al. (2019) classified the fruits of Mimosa ophthalmocentra Mart. Benth. into five maturity stages, based on color, and performed germination tests for each stage with and without treatment to overcome dormancy. They found that dormancy intensifies from the fourth class (light brown). In class 3 (yellow-brown), the percentage of germination did not differ between treatments with $(82 \%)$ and without $(77 \%)$ dormancy overcoming, which indicates that for this species, the seeds are not dormant when at the point of physiological maturity.

When subjected to water at $100{ }^{\circ} \mathrm{C}$, seeds collected from brown fruits with darkened regions showed better germination performance compared to those from green fruits (Table 2). In the absence of dormancy overcoming treatment, seeds obtained from yellowish green fruits with purplish edges (T2) showed a higher percentage of normal seedlings (98.4\%) compared to those obtained from brown fruits $(92.8 \%)$. Therefore, these results corroborate those of Almeida (2013), who identified yellowish green fruits as the point of morphological maturity. 
A characteristic of seeds of the Fabaceae family is their thick coat, which makes it waterproof and prevents the entry of water. This occurs because these seeds have some wraps, among them, waxy cuticle, suberin, palisade tissue and the macrosclereid layers (Cardoso, 2004). Lima et al. (2018), performing image analysis technique in Bowdichia virgilioides Kunth, observed that this species may show different seed coat thicknesses.

The mean germination time was not different between treatments (Table 3). It is worth pointing out that the treatment referring to seeds from yellowish green fruits with purplish edges with dormancy overcoming (T1) was not included in the analyses of the variables mean germination time and lengths of shoots and roots since its germination was null.

Table 3 - Mean seed germination time (MGT), shoot length (SL) and primary root length (PRL) of Bowdichia virgilioides Kunth. seedlings

\begin{tabular}{lccc}
\hline Treatments & MGT (days) & SL $(\mathrm{cm})$ & PRL $(\mathrm{cm})$ \\
\hline T2 & $13.57 \mathrm{a}$ & $1.73 \mathrm{a}$ & $2.71 \mathrm{a}$ \\
T3 & $13.33 \mathrm{a}$ & $1.03 \mathrm{~b}$ & $1.65 \mathrm{~b}$ \\
T4 & $16.41 \mathrm{a}$ & $1.59 \mathrm{a}$ & $2.59 \mathrm{a}$ \\
\hline MSE & 4.18 & 0.02 & 0.04 \\
CV\% & 14.15 & 9.59 & 8.84 \\
p-value & 0.06 & $<0.0001$ & $<0.0001$ \\
\hline
\end{tabular}

Means in columns followed by equal letters do not differ statistically by Tukey test $(\alpha=0.05)$

Treatments without dormancy overcoming showed greater vigor of the seeds, considering that the average lengths of shoots and roots, based on the initial number of seeds, are indicators of vigor (Guedes et al., 2009).

\section{Experiment 2}

The moisture content of the seeds from the fruits after the seventh week of floral anthesis was on average $8.94 \%$ with Confidence Interval-Cl${ }_{95 \%}$ of $8.94 \%$ $\pm 0.98 \%$.

In the treatment without dormancy overcoming, in only one replicate, among the 10 used, there was germination of two seeds, and only one formed a normal seedling. In the treatment with immersion of seeds in water at $100 \stackrel{\circ}{\circ}$ for 10 seconds, germination $(87.7 \%)$ and the formation of normal seedlings $(76.8 \%)$ were high (Figure 2).

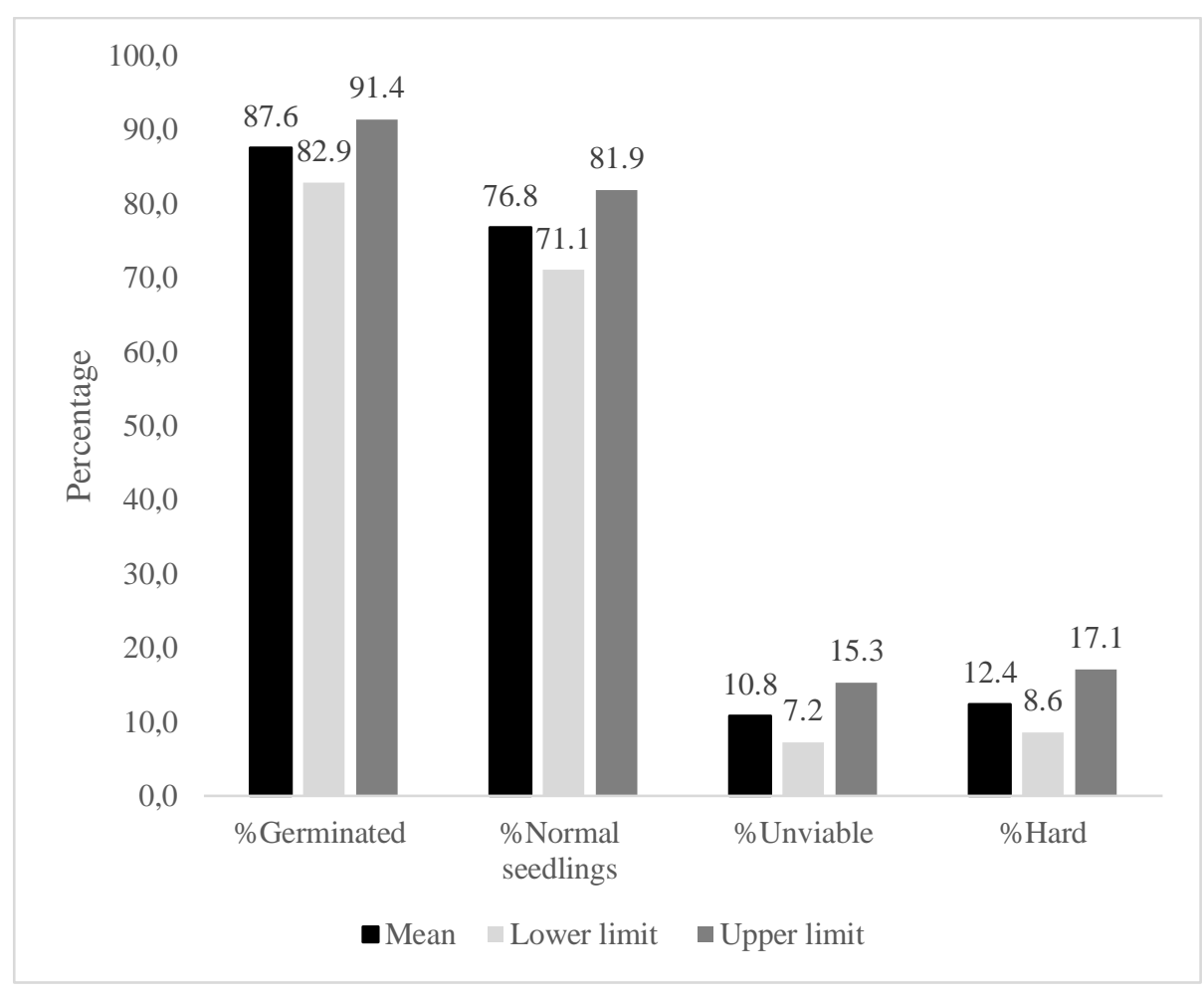

Figure 2 - Confidence intervals $(\alpha=0.05)$ of binomial distribution for germination percentage, percentage of normal seedlings, percentage of unviable seeds and percentage hard seeds of Bowdichia virgilioides Kunth, resulting from treatment to overcome dormancy. 
Seeds obtained from fruits after the seventh week of floral anthesis showed high degree of dormancy because, without immersion in water at $100^{\circ} \mathrm{C}$ for 10 seconds, germination was virtually zero, occurring only in two seeds out of a total of 250. These results confirm that fruit maturity influences the dormancy of $B$. virgilioides seeds.

According to Bewley et al. (2013), seed coat impermeability increases as the moisture content decreases, and the moisture range within which the impermeability is consolidated is between 2 and $20 \%$. For studies that reported dormancy of $B$. virgilioides, the moisture content of the seeds was between 8.6 and 9.0\% (Andrade et al., 1997; Albuquerque et al., 2007; Smiderle \& Schwengber, 2011), so the moisture range within which the seed of this species becomes impermeable can be between 8.6 and $9.0 \%$. In the present study, the moisture content of dormant seeds was $8.94 \%$.

The results of this study may contribute to the practice of cultivating $B$. virgilioides, since it was found that the application of dormancy overcoming methods will not always be necessary. Reducing the indication of the use of sulfuric acid, the main technique employed to overcome dormancy of $B$. virgilioides seeds, facilitates the use of this species in reforestation programs because, if the seeds are collected at the adequate point of physiological maturity, there will be no need to use sulfuric acid, a product of difficult handling and disposal.

\section{Conclusions}

Bowdichia virgilioides seeds, collected from yellowish green fruits and brown fruits with darkened regions, do not show dormancy.

The establishment of dormancy occurs after the seventh week of floral anthesis when the fruits are predominantly darkened, dried and brittle.

\section{Acknowledgments}

To CAPES for granting the financial support through the Graduate Scholarship and funding the Institute of Environment and Water Resources - INEMA, through the Reference Center for Forest Restoration of the Atlantic Forest Biome - CRRF/MA.

\section{References}

Albuquerque KS, Guimarães RM, Almeida IF de, Clemente A. da CS (2007) Métodos para a superação da dormência em sementes de sucupira-preta (Bowdichia virgilioides KUNTH.). Ciência e Agrotecnologia 31(6): 1716-1721.

Almeida DS (2013) Maturação de frutos e sementes de sucupira preta (Bowdichia virgilioides Kunth - Fabaceae - Faboideae). UFRB (Dissertação de mestrado em Recursos Genéticos Vegetais).
Andrade ACS de, Loureiro MB, Souza ADO (1997) Quebra de dormência de sementes de sucupira-preta. Pesquisa Agropecuária Tropical 32(5): 465-469.

Bewley JD, Bradford K, Hilhorst HWM, Nonogaki H (2013) Seeds: Physiology of Development, Germination and Dormancy, Springer, cap 6, p. 247-295

Brasil (2009) Ministério da Agricultura, Pecuária e Abastecimento. Regras para análise de sementes. Brasília. 399p.

Brasil (2013) Ministério da Agricultura, Pecuária e Abastecimento. Instruções para análise de sementes de espécies florestais, Brasília. $98 \mathrm{p}$.

Botezelli L, Davide AC, Malavasi MM (2000) Características dos frutos e sementes de quatro procedências de Dipteryx alata Vogel (Baru). Cerne 6(1): 9-18.

Botini N, Antoniazz CA, Souza KA de, Añez RB (2015) Estudo etnobotânico das espécies Bowdichia virgilioides e Pterodon pubescens na comunidade salobra grande município de Porto Estrela, MT. Biodiversidade 14(2): 19-31.

Cardoso VJM (2004) Dormência: estabelecimento do processo In: Ferreira AG, Borghetti F (orgs.) Germinação: do básico ao aplicado, Artmed, cap. 5, p.95-108p.

Cardoso VJM (2009) Conceito e classificação da dormência em sementes. Oecologia Brasiliensis 13(4): 619-631.

Cardoso DBOS. Bowdichia in Flora do Brasil 2020 em construção. Jardim Botânico do Rio de Janeiro. Disponível em http://reflora.jbrj.gov.br/reflora/floradobrasi//FB29489.

Acesso em 09 Out. 2019.

Carvalho FJ, Santana DG, Araújo LB (2018) Why analyze germination experiments using Generalized Linear Models? Journal of Seed Science 40(3): p.281287.

Coêlho CB, Paulo FV de L, Viana BL (2019) Dormancy overcoming in Bowdichia virgilioides Kunth seeds. Ciência Agrícola (17)2: 73-79.

Dorai-Raj S (2014) Packages binomial confidence intervals for several parameterizations. Disponível em: https://cran.r-project.org/web/packages/binom/binom.pdf. Acesso em 17 Out. 2019.

Guedes RS, Alves EU, Gonçalves EP, Viana JS, Medeiros MS de, Lima CR de (2009) Teste de comprimento de plântula na avaliação da qualidade fisiológica de sementes de Erythrina velutina Willd. Semina: Ciências Agrárias 30(4): 793-802. 
Graves S, Piepho H-P, Selzer L, Dorai-Raj S (2019) Package 'multcompView'. 2019. Disponível em: https://cran.r-pro-

ject.org/web/packages/multcompView/multcompView. pdf. Acesso em 28 mar. 2020.

Leite MS, Nogueira NW, Freitas RMO de, Leite TS, Guimarães PP. (2019) Maturação fisiológica e dormência em sementes de jurema-de-embira (Mimosa ophthalmocentra). Advances in Forestry Science 6(2):659-663.

Lenth R, Singmann, Love J, Buerkner $\mathrm{P}$, Herve $\mathrm{M}$ (2020) Package 'emmeans'. 2020. Disponível em: https://cran.rproject.org/web/packages/emmeans/emm eans.pdf. Acesso em: 28 de mar. 2020.

Lima JME, Smiderle OJ, Oliveira JA, Carvalho MLM (2018). Técnicas de análise de imagem para caracterização da qualidade de sementes de paricarana (Bowdichia virgilioides Kunth). Ciência Florestal 28(3): $1202-1216$.

Lorenzi H (2009) Árvores brasileiras: manual de identificação e cultivo de plantas arbóreas nativas do Brasil. Instituto Plantarum, $384 \mathrm{p}$.

Machado MSL, Bruno KA, Melo M de O, Koike MK (2018) Fitoterapia brasileira: análise dos efeitos biológicos da sucupira (Bowdichia virgilioides e Pterodon emarginatus). Brazilian Journal of Natural Sciences 2(1): 15-21.

Müller EM, Gibbert P, Binotto T, Kaiser DK, Bortolin MF (2016) Maturação e dormência em sementes de Peltophorum dubium (Spreng) Taub. de diferentes árvores matrizes. Iheringia 71(3): 222-229.

Nascimento RC, Freire OO, Ribeiro LS, Araújo MB, Finger FL, Soares MA, Wilcken CF, Zanuncio JC, Ribeiro WS (2019) Ripening of bananas using Bowdichia virgilioides Kunth leaves. Scientific Reports 9(1):1-6.

Nogueira NW, Martins HVG, Batista DS, Ribeiro MCC, Benedito CP (2010) Grau de dormência das sementes de jucá em função da posição na vagem. Revista Verde 5(1): 39-42.
Nogueira NW, Ribeiro MCC, Freitas RMO, Martins HVG, Leal, CCP (2013) Maturação fisiológica e dormência em sementes de sabiá (Mimosa caesalpiniifolia Benth.). Bioscience Journal 29(4): 876-883.

Nakagawa J, Cavariani C, Martins CC, Coimbra, RA (2007) Intensidade de dormência durante a maturação de sementes de mucunã- preta. Revista Brasileira de Sementes 29(1): 165-170.

R Core Team (2019). R: A language and environment for statistical computing. R Foundation for Statistical Computing, Vienna, Austria. URL https://www.Rproject.org/.

Rosa-Magri MM, Meneghin SP (2014) Avaliação das características germinativas da espécie arbórea sucupira-preta (Bowdichia virgilioides Kunth - Fabaceae). Bioikos 28(1): 3-10.

Silva ACM, Santos MP, França AS, Silva VC, Silva LE, Figueiredo US de, Dall'Oglio EL, Sousa Júnior PT de, Lopes CF, Baviera, AM, Kawashita NH (2015) Acute and subchronic antihyperglycemic activities of Bowdichia virgilioides roots in non-diabetic and diabetic rats. Journal of Intercultural Ethnopharmacology 4(1): 57- 63.

Silva TL, Fernandes JB, Silva MF das GF da, Consolaro HN, Sousa LRF de, Vieira PC (2019) New cathepsin V inhibitor from stems of Bowdichia virgilioides. Brazilian Journal of Pharmacognosy 29: 491-494.

Smiderle OJ, Schwengber LAM (2011) Superação da dormência em sementes de paricarana (Bowdichia virgilioides Kunth.). Revista Brasileira de Sementes 33(3): 407-414.

Smiderle OJ, Sousa RCP de (2003). Dormência em sementes de paricarana (Bowdichia virgilioides Kunth Fabaceae- Papilionoidae) Revista Brasileira de Sementes 25 (2): 48-52. 